\title{
Genetically Predicted Cigarette Smoking in Relation to Risk of Polycystic Ovary Syndrome [Corrigendum]
}

Tao Y, Liu B, Chen Y, et al. Clin Epidemiol. The authors apologize for this error. 2021;13:527-532.

The authors have advised there is an error in affiliation 1 on page 527. "Tongde Hospital" should read "Tongde Hospital of Zhejiang Province".

\section{Publish your work in this journal}

Clinical Epidemiology is an international, peer-reviewed, open access, online journal focusing on disease and drug epidemiology, identification of risk factors and screening procedures to develop optimal preventative initiatives and programs. Specific topics include: diagnosis, prognosis, treatment, screening, prevention, risk factor modification,

systematic reviews, risk \& safety of medical interventions, epidemiology \& biostatistical methods, and evaluation of guidelines, translational medicine, health policies \& economic evaluations. The manuscript management system is completely online and includes a very quick and fair peer-review system, which is all easy to use. 